Historia: Jurnal Program Studi Pendidikan Sejarah

Vol. 2 No. 2 (2017):17-32

P-ISSN 2301-8305

E- ISSN 2599-0063

\title{
PERUBAHAN KEHIDUPAN SOSIAL EKONOMI MASYARAKAT PASCA PERKEBUNAN KARET DI DESA PARIT PACITAN SUNGAI UNGAR TANJUNG BATU
}

\section{CHANGES IN SOCIO-ECONOMIC LIFE OF SOCIETY POST-PLANTATION RUBBER IN PARIT PACITAN VILLAGE SUNGAI UNGAR TANJUNG BATU}

\author{
Afrinel Okwita $^{1}$, Norhayati ${ }^{2}$ \\ ${ }^{\text {I}}$ (Prodi Pendidikan Sejarah, FKIP, Universitas Riau Kepulauan, Indonesia) \\ ${ }^{2}$ (Prodi Pendidikan Sejarah, FKIP, Universitas Riau Kepulauan, Indonesia) \\ laaftuteh@gmail.com, ${ }^{2}$ Norhayati@gmail.com
}

\begin{abstract}
Abstrak
Adapun tujuan dalam penelitian ini adalah mendeskripsikan (1) perubahan kehidupan sosial ekonomi masyarakat pasca perkebunan karet Desa Parit Pacitan Sungai Ungar Tanjung Batu. Metode yang digunakan dalam penelitian ini jenis kualitatif dengan metode deskriptif dalam penelitian ini sumber data berasal dari hasil observasi, wawancara, dan dokumentasi. Menggunakan sumber data primer dan skunder. Teknik analisis data yang digunakan adalah pengumpulan data, reduksi data, penyajian data, dan penarikan kesimpulan. Perubahan mata pencaharian mengakibatkan perubahan di berbagai aspek kehidupan terutama bagi kondisi sosial-ekonomi mereka. Hasil penelitian menunjukkan bahwa kondisi sosial masyarakat Desa Parit Pacitan pada umumnya pendidikan semangkin meningkat. Interaksi sosial yang ada dalam masyarakat Desa Parit Pacitan semangkin menurun disebabkan karena adanya perubahan mata pencaharian, masyarakat lebih mementingkan untuk pergi berkebun untuk menghasilkan getah. Selain itu juga mengakibatkan pendapatan masyarakat semangkin meningkat, dan gaya hidup masyarakat juga berubah awalnya mereka hanya memakan jagung, ubi dan ikan-ikan yang yang ada disungai namun sekarang masyarakat sudah bisa menikmati makanan-makanan seperti ayam, daging, sosis, nugget, spageti, ikan laut, buah-buahan dll sebaginya. Mereka juga sudah bisa membuat rumah yang bagus, motor bagus, baju yang bagus dan alat-alat elektronik lainnya.
\end{abstract}

Kata Kunci; Perubahan, Kehidupan sosial ekonomi, Perkebunan karet

\begin{abstract}
The purpose of this study is to describe (1) changes in the socio-economic life of the community after the rubber plantation in Parit Village, Pacitan, Ungar River, Tanjung Batu. The method used in this study is a qualitative type with a descriptive method in this study. Data sources come from the results of observations, interviews, and documentation. Using primary and secondary data sources. Data analysis techniques used are data collection, data reduction, data presentation, and conclusion. Changes in livelihoods have resulted in changes in various aspects of life, especially for their socio-economic conditions. The results of the study show that the social conditions of the Pacitan Parit Village community in general are likely to increase. The social interactions that exist within the community of Pacitan Village are likely to decrease due to changes in livelihoods, the community is more concerned with going to the garden to produce sap. In addition, it also results in increased income for the community, and people's lifestyles also change, initially they only eat corn, sweet potatoes and fish that are in the river, but now people can enjoy foods such as chicken, meat, sausages, nuggets, spaghetti, sea fish, fruits etc. They have also been able to make good houses, good motorbikes, good clothes and other electronic devices.
\end{abstract}


Historia: Jurnal Program Studi Pendidikan Sejarah

Vol. 2 No. 2 (2017):17-32

P-ISSN 2301-8305

E- ISSN 2599-0063

Keywords; Change, Social and economic life, Rubber plantation

\section{PENDAHULUAN}

Manusia adalah makhluk sosial, mereka memiliki naluri untuk hidup dengan orang lain. Adanya hubungan yang mereka lakukan, kemudian timbulah kelompokkelompok sosial yang terbentuk karena adanya persamaan kepentingan. Biasanya kelompok sosial yang lebih luas dapat disebut dengan masyarakat. Suatu masyarakat akan selalu bersifat dinamis. Mereka akan selalu berkembang seiring dengan berjalannya waktu. Perubahan dalam masyarakat pada prinsipnya merupakan suatu proses terusmenerus, artinya bahwa setiap masyarakat pada kenyataannya akan mengalami perubahan, akan tetapi perubahan antara masyarakat yang satu dengan yang lainnya berbeda. Dampak adanya perubahan tersebut dapat berupa kemajuan atau pun kemunduran bagi masyarakat sekitar (Saputri, 2012:1).

Perubahan dalam masyarakat memang telah ada sejak dulu. Namun, dewasa ini perubahan-perubahan tersebut berjalan dengan sangat cepatnya sehingga membingungkan manusia yang menghadapinya, yang sering berjalan dengan konstan. Ia memang terikat oleh waktu dan tempat. Akan tetapi, karena sifatnya yang berantai, perubahan terlihat berlangsung terus, walau diselingi keadaan masyarakat mengadakan reorganisasi unsur-unsur struktur masyarakat yang terkena perubahan (Soekanto, 2010:259).

Desa Parit Pacitan merupakan Desa Sungai Ungar yang dinamakan langsung pada penduduk setempat. Karena kebanyakan dari mereka yang transmigran dari pulau jawa, maka lokasi atau desa nya disebut dengan Desa Pacitan, karna tempatnya yang menyerupai pacitan banyak tanaman-tanaman yang tumbuh subur dan daun-daun yang berhijauan maka desa tersebut dinamakan pacitan, dan parit itu diambil dari banyaknya aliran air yang memanjang di sepanjang jalan dan berbentuk parit-parit kecil, berbelokbelok maka desa tersebut dinamakan desa parit pacitan. lokasinya terletak di dekat Kundur Utara. Parit Pacitan merupakan suku yang banyak transmigran dari luar terutama dari Pulau Jawa. Desa Parit Pacitan penduduknya mayoritas beragama Islam. Desa Parit Pacitan letaknya jauh dari perkotaan sehingga masyarakatnya sulit untuk mendapatkan 
Historia: Jurnal Program Studi Pendidikan Sejarah

Vol. 2 No. 2 (2017):17-32

P-ISSN 2301-8305

E- ISSN 2599-0063

kemudahan seperti layaknya tinggal di kota. Parit Pacitan merupakan desa yang letak wilayahnya sangat luas namun masih banyak hutan yang masih dipenuhi dengan pohonpohon besar.

Kondisi masyarakat Parit Pacitan pada saat itu masih sangat sulit, dengan hanya sebagai pencari ikan di sungai yang hasilnya tidak mencukupi dan harus memenuhi kebutuhan hidup keluarganya. Namun masyarakat tidak ada pilihan lain selain mencari ikan dan bertani menanam ubi dan jagung karena hanya itulah satu-satunya mata pencaharian mereka, dan mereka tetap harus bertahan demi menghidupi keluarganya. Namun dengan keadaan alam ikan-ikan tersebut hampir punah di sebabkan oleh adanya kemarau yang panjang dan kebakaran yang menyebabkan masyarakat setempat tidak dapat mencari ikan dan berkebun lagi.

Dengan adanya perkebunan pinang maka secara perlahan-lahan masyarakat merasakan pendistribusian seperti beras, minyak, tepung dan makanan lainnya sudah mulai bisa dirasakan oleh penduduk setempat dan masyarakat tidak lagi memakan ubi dan jagung lagi atau gaplek yang di buat oleh masyarakat Parit Pacitan, karena seiring dengan adanya pemerintah memberikan modal untuk membuka perkebunan pinang maka pemerintah telah memberikan dan menyediakan barang- barang dan makanan sesuai dengan apa yang diinginkan.

Seiring berjalannya waktu dan zaman yang semangkin maju. Pada tahun 1979 pemerintah mengadakan sosialisasi terhadap masyarakat Parit Pacitan untuk mengadakan pergantian penanaman baru yaitu tanaman karet kepada masyarakat setempat guna untuk memperbaiki perekonomian masyarakat yang awalnya tanaman pinang yang kurang menjanjikan hasilnya menjadi tanaman karet, dalam sosialisasi tersebut pemerintah mengadakan program untuk mengembangkan tanaman karet sebagai mata pencaharian utama penduduk setempat. Tanaman karet diharapkan dapat meningkatkan perekonomian masyarakat. Pemerintah memberikan penjelasan lebih mendalam tentang perkebunan karet. Tanaman karet yang sudah berusia \pm 5 tahun dapat disadap dan dipanen hasilnya. Penduduk disana merasa senang dengan program tersebut sehingga mereka dapat memenuhi kebutuhan hidupnya. 
Historia: Jurnal Program Studi Pendidikan Sejarah

Vol. 2 No. 2 (2017):17-32

P-ISSN 2301-8305

E- ISSN 2599-0063

Dengan hadirnya perkebunan karet masyarakat Parit Pacitan mulai mengalami perubahan dalam kehidupannya. Mereka tidak hanya bekerja saja namun mereka mulai mengenal pendidikan dan juga mengenal alat transportasi seperti sepeda. Di Parit Pacitan juga sudah didirikan sekolah sehingga masyarakat dengan mudah bisa mendapatkan pendidikan. Namun hanya sebagian penduduk saja yang bersekolah pada saat itu dan sebagian penduduk lainnya hanya mementingkan bekerja dan terus bekerja guna untuk memperbanyak lahan atau perkebunan mereka. Pada masa itu pendidikan banyak dinikmati oleh kaum laki-laki sedangkan wanita banyak yang tidak sekolah karena orang tua mereka beranggapan bahwa takdir wanita itu mengurus keluarga dan anak-anak sehingga tidak membutuhkan pendidikan. Berdasarkan latar belakang dan rumusan masalah dalam penelitian ini adalah bagaimana perubahan kehidupan sosial ekonomi masyarakat pasca perkebunan karet di Desa Parit Pacitan Sungai Ungar Tanjung Batu?

\section{METODOLOGI}

\section{A. Jenis Penelitian}

Penelitian ini menggunakan jenis penelitian kualitatatif. Penelitian kualitatif adalah penelitian tentang riset yang bersifat deskriptif dan cenderung menggunakan analisis. Proses dan makna (perspektif subjek) lebih ditonjolkan dalam penelitian kualitatif.

\section{B. Tempat dan Waktu Penelitian}

Penelitian ini mengambil lokasi di desa Parit Pacitan Sungai Ungar Tanjung Batu, lokasi tersebut merupakan salah satu dari banyak wilayah yang memliki petani karet di Kepri.

\section{Metode Penelitian}

Penelitian ini adalah penelitian kualitatif-deskriptif. Denzin dan Lincoln (dalam Moleong 2012:5), menyatakan bahwa penelitian kualitatif adalah penelitian yang menggunakan latar alamiah, dengan maksud menafsirkan fenomena yang terjadi dan dilakukan dengan jalan melibatkan berbagai metode yang ada. Dalam penelitian kualitatif 
Historia: Jurnal Program Studi Pendidikan Sejarah

Vol. 2 No. 2 (2017):17-32

P-ISSN 2301-8305

E- ISSN 2599-0063

metode yang biasanya dimanfaatkan adalah wawancara, pengamatan, pemanfaatan dokumen.

1. Sumber Data

a. Sumber data Primer

Sumber data primer merupakan data yang diperoleh dengan cara menggali sumber asli secara langsung melalui responden. Perolehan data melalui wawancara dan pengamatan langsung dilapangan. Sumber data utama yang dimaksudkan Lofland dan lofland (dalam Ibrahim, 2015:69). Adalah sumber utama yang dapat memberikan informasi, fakta dan gambaran pristiwa yang diinginkan dalam penelitian. Atau sumber pertama dimana sebuah data dihasilkan dalam penelitian kualitatif, sumber data utama itu adalah kata-kata dan tindakan orang yang diamati atau diwawancarai.

b. Sumber Sekunder

Sumber data sekunder merupakan sumber yang tidak langsung memberikan data kepada pengumpul data, misalnya lewat orang lain atau lewat dokumen Sugiyono (2011:225). Sumber data sekunder dalam penelitian ini meliputi studi pustaka, media cetak maupun media elektronik, serta catatan dilapangan. Peneliti menggunakan catatan lapangan dalam mencari sumber data yang ada di desa Parit Pacitan karena peneliti ingin melihat kondisi sosial ekonomi masyarakat pasca perkebunan karet.

\section{Teknik Pengumpulan Data}

Teknik pengumpulan data merupakan langkah yang paling strategis dalam penelitian, karena tujuan utama dari penelitian ini adalah mandapatkan data Sugiyono (2011:225). Adapun teknik pengumpulan data yang digunakan dalam penelitian ini antara lain:

\section{a. Pengamatan (observasi)}

Observasi adalah metode pengumpulan data dimana peneliti mencatat informasi sebagimana yang mereka saksikan selama penelitian. Dimana dalam penelitian ini menggunakan observasi terus terang atau tersamar. Dalam hal ini, peneliti melakukan pengumpulan data menayatakan terus terang kepada sumber data, bahwa ia sedang melakukan penelitian Sugiyono (2011:226). Observasi yang dilakukan yaitu melakukan 
Historia: Jurnal Program Studi Pendidikan Sejarah

Vol. 2 No. 2 (2017):17-32

P-ISSN 2301-8305

E- ISSN 2599-0063

penelitian/pengamatan secara langsung terhadap kehidupan ataupun interaksi sosial ekonomi masyarakat Parit Pacitan.

b. Wawancara

Menurut Esterberg (2011) wawancara adalah merupakan pertemuan dua orang untuk bertukar informasi dan ide melaui Tanya jawab, sehingga dapat dikonstruksikan makna suatu topik tertentu. Wawancara digunakan sebagai teknik pengumpulan data dan bisa digunakan untuk mengetahui hal-hal dari responden yang lebih mendalam.

c. Dokumentasi

Dokumen atau dokumentasi dalam penelitian mempunyai dua makna. Yang pertama dokumen yang dimaksudkan sebagai alat bukti tentang sesuatu, termasuk catatan-catatan, foto, rekaman, video atau apapun yang dihasilkan oleh seorang peneliti. Dokumen bentuk ini disebut dengan dokumentasi kegiatan/kenang-kenangan. Kedua, dokumen yang berkenaan dengan pristiwa atau momen atau kegiatan yang telah lalu, yang dihasilkan dalam sebuah informasi, fakta dan data yang diinginkan dalam penelitian (Ibrahim, 2015:93).

\section{Teknik Analisis Data}

Teknik analisis data dimaksudkan untuk mencari jawaban tentang permasalahan yang dirumuskan sebelumnya. Miles dan Huberman (dalam Idrus, 2009:147). Mengemukakan bahwa aktivitas dalam analisis data kualitatif dilakukan secara interaktif dan berlangsung secara terus menerus sampai tuntas., sehingga datanya sudah jenuh. Analisis data model Miles dan Huberman yang terdiri dari empat hal utama, yaitu pengumpulan data, reduksi data, penyajian data, dan penarikan kesimpulan atau verifikasi. Proses analisis data dilakukan dengan menggunakan beberapa kriteria diantaranya pengumpulan data, reduksi data, penyajian data dan penarikan kesimpulan.

\section{PEMBAHASAN}

Kecamatan kundur merupakan satu dari tiga kecamatan yang terbentuk berdasarkan UU No. 53 Tahun 1999. Tanjung batu merupakan salah satu wilayah di Kabupaten Karimun Provinsi Kepulauan Riau. Tanjung Batu Kota adalah ibukota dari 
Historia: Jurnal Program Studi Pendidikan Sejarah

Vol. 2 No. 2 (2017):17-32

P-ISSN 2301-8305

E- ISSN 2599-0063

kecamatan Kundur yang merupakan salah satu Kecamatan tertua di Kabupaten Karimun. Tanjung Batu kota selain merupakan daerah kaya akan sumber daya alam yang dijadikan komiditi terbesar di Kabupaten Karimun, selain itu pula menyimpan situs sejarah unik yang jika kita kaji lebih mendalam akan terasa sangat menarik. Hal yang sangat miris dirasakan adalah kecendrungan masyarakat untuk memahami sejarah daerahnya sendiri sudah sangat menurun.

Masyarakat desa dalam kehidupan sehari-harinya menggantungkan pada alam. Alam merupakan segalanya bagi penduduk desa, karena alam memberikan apa yang dibutuhkan manusia bagi kehidupannya. Mereka mengolah alam dengan peralatan yang sederhana untuk dipetik hasilnya guna memenuhi kebutuhan sehari-hari. Seperti diketahui masyarakat perdesaan sering diindentikkan sebagai masyarakat agraris, yaitu masyarakat yang kegiatan ekonominya terpusat pada pertanian. Seperti halnya yang ada di Desa Parit Pacitan Kabupaten Karimun ini yang memang sebagian besar warganya bekerja sebagai petani dan juga nelayan. Mereka menggantungkan hidupnya dalam bidang peranian dan nelayan. Karena memang didukung dengan kondisi tanah yang subur dan sungai yang dekat dengan penduduk sekitar maka dari itu tidak heran jika warga memanfaatkan kesuburan alam tersebut untuk menopang kehidupan mereka sehari-hari. .

1) Kehidupan Sosial Masyarakat

Kehidupan sosial masyarakat tidak statis namun berubah secara dinamis. Seiring dengan berkembangnya zaman dan dinamika pertumbuhan masyarakat. Seperti halnya yang terjadi pada masyarakat Parit Pacitan perubahan tidak terjadi pada daerah perkotaan namun pada daerah perdesaan seperti halnya didesa Parit Pacitan. Dahulunya masyarakat bekerja sebagai nelayan. Sebagai anggota masyarakat yang hidupnya selalu berdampingan dengan orang lain, tentu saja interaksi sangat diperlukan dalam kehidupan sehari-hari. Adanya interaksi tersebut memudahkan kita untuk berkomunikasi dan melakukan hubungan timbal balik dengan orang-orang yang ada disekitar kita. Ada beberapa bentuk yang dilakukan oleh warga Parit Pacitan dalam proses interaksi ini yaitu kerja sama, Seperti halnya interaksi yang dilakukan oleh warga masyarakat di Desa Parit Pacitan ini mereka saling menjalin hubungan baik, itu terbukti ketika Desa tersebut sangat sulit untuk mendapatkan makanan seperti ubi, jagung dll, mereka saling 
Historia: Jurnal Program Studi Pendidikan Sejarah

Vol. 2 No. 2 (2017):17-32

P-ISSN 2301-8305

E- ISSN 2599-0063

membantu satu sama lain dalam mendapatkan makanan tersebut, mereka juga ada yang mencari ikan di sungai dan hasilnya dibagi kepada warga setempat supaya dapat samasama makan.

Masyarakat Parit Pacitan hidupnya saling damai dan saling berbagi. Karena tingkat persaudaraan mereka sangat kuat. Namun sekarang dengan adanya perkebunan karet ketika pada musim panas selalu bekerja mencari uang demi mendapatkan getah karet yang banyak dan cepat dipanen. Kehidupan sosial masyarakat telah berubah rasa saling tolong menolong dan berbaginya tidak sekental seperti dulu, karena ekonomi yang semangkin tinggi maka permintaan masyarakat semangkin tinggi seperti mereka menginginkan rumah yang mewah, mobil, baju yang mahal, Hp yang canggih dan juga pendidikan yang tinggi dan lain sebaginya.

Pada umumnya sekarang sudah marak dengan android, tua, muda sudah tidak asing lagi dengan namanya facebook karena pada dasarnya semua momen dan semua aktivitas bisa dikatakan tidak sah jika tidak di update itulah yang terjadi pada zaman sekarang sudah tidak heran lagi. Semuanya sudah dikenal dikalangan masyarkat, rumah mewah yang selalu diidamkan oleh semua orang dan segala isi didalamnya. Dilihat didesa Parit Pacitan rumahnya sudah cukup bagus ada yang bertingkat ada yang masih lantai dasar namun rata-rata mereka sudah mempunyai kendaraan masing-masing baik itu motor maupun mobil.

Termasuk pendidikannya semangkin tahun anak-anaknya semangkin meningkat sekolahnya awalnya dulu hanya tamatan SD, Rendahnya tingkat pendidikan yang ada menjadikan mereka memiliki sedikit kesempatan untuk bekerja diluar sebagai petani. Mereka tidak mampu bersaing dengan mereka yang berpendidikan lebih tinggi dan keahlian yang dimiliki. Oleh karena itu mereka hanya bisa bekerja semampu mereka tanpa memiliki keahlian khusus, untuk meneruskan pekerjaan petani/buruh tani yang sudah ditekuni oleh orang tua mereka.

Pada zaman dahulu warga masyarakat tidak mengenal pendidikan namun dengan seiringnya waktu dan berkembangnya zaman telah terjadi perubahan kehidupan masyarakat. Sejak masyarakat bekerja sebagai petani karet kehidupan masyarakat sangat berubah dari segi pendidikan, pendapatan, mata pencaharian dan juga sosial ekonominya 
Historia: Jurnal Program Studi Pendidikan Sejarah

Vol. 2 No. 2 (2017):17-32

P-ISSN 2301-8305

E- ISSN 2599-0063

sangat berubah. Dengan masyarakat bermata pencaharian sebagai penyadap karet pendidikan masyarakat sekarang jauh lebih baik. Awalnya mereka tidak bersekolah ada juga hanya tamatan SD dan rata-rata awal-awal adanya perkebunan karet mereka tamatan $\mathrm{SD}$, namun dengan zaman yang semangkin maju maka pendidikannya juga semangkin meningkat hingga mencapai SMP, SMA bahkan sekarang anak-anaknya banyak yang sekolah diperguruan tinggi.

Desa Parit Pacitan sekarang banyak yang sekolah mencapai sarjana karena selain semangkin tinggi ilmu pengetahuan semangkin tinggi juga persaingan dunia kerja. Maka dari itu berangsur-angsur dari mereka sekolah kejenjang yang lebih tinggi baik itu di Tanjung Pinang, Tanjung Balai, Pekanbaru, Batam, Padang dan lain-lain sebagainya. Pendidikan sangat penting bagi kehidupan manusia, dengan adanya pendidikan kelak mereka akan bisa membangun suatu masyarakat yang maju. Adanya pendidikan ini juga akan mempengaruhi taraf hidup mereka. Adanya pendidikan yang cukup memadai, mereka bisa mengembangkan bakat dan kreativitas mereka yang nantinya dapat dijadikan penghasilan ekonomi ataupun lapangan pekerjaan bagi orang-orang sekitar. Dalam meningkatkan mutu pendidikan yang ada, perlunya kerja sama yang dilakukan oleh pemerintah dan warga sekitar. Adanya pandangan yang sama tentang pentingnya pendidikan akan memudahkan mereka untuk menyekolahkan anak-anaknya kejenjang yang lebih tinggi.

2) Kehidupan Ekonomi Masyarakat

Permasalahan yang ditimbulkan adanya perubahan mata pencaharian tersebut sangat berdanpak pada kondisi ekonomi masyarakat sekitar. Akibat dari kurangya ikanikan di sungai menyebabkan penduduk setempat berimbas pada tempuruknya aktivitas ekonomi masyarakat.

Keadaan tersebut tentu saja sangat mempengaruhi pendapatan ekonomi warga sekitar, dimana biasanya memang sebagian besar warga bekerja sebagai petani dan mencari ikan di sungai-sungai namun dengan kondisi yang tidak memungkinkan maka pemerintah setempat pun mendapatkan benih tanaman pinang pada waktu itu, maka masyarakat dengan kondisi yang sudah banyak hutan terbakar akhirnya mereka membuat 
Historia: Jurnal Program Studi Pendidikan Sejarah

Vol. 2 No. 2 (2017):17-32

P-ISSN 2301-8305

E- ISSN 2599-0063

lahan untuk menanam tanaman pohon pinang tersebut sebagai pengganti akibat kebakaran dan ikan yang tidak memadai lagi.

Dimana banyak lahan pertanian yang terkena akibat kebakaran dan otomatis tanaman semua habis akibat kebakaran ketidak pastian pendapatan dari aktivitas petani saat itu menjadikan mereka harus bekerja diluar sektor pertanian mereka menanam tanaman kopi dan pinang guna untuk mencukupi kebutuhan hidup mereka. Kehidupan sementara selagi dalam sektor penanaman kopi dan pinang masih mengalami penurunan.

Para petani/buruh untuk sementara meninggalkan aktivitas bertaninya dan mencari ikan karena memang waktu itu tidak memungkinkan untuk menggarap lahan pertanian, apalagi mereka yang kehilangan lahan pertanian. Mereka pada waktu itu sehari-harinya bekerja sebagai penananam pinang dan kopi. Pendapatan yang mereka peroleh sehari-hari dengan menjadi penanam kopi pinang telah membantu mereka untuk memenuhi kebutuhan sehari-hari.

Mata pencaharian mereka didapatkan mereka untuk makan sehari-hari yaitu dari hasil menanam kopi dan pinang, karena pemerintah setempat ingin masyarakatnya berkebun. Karena dilihat dari tingkat kesuburan tanahnya desa tersebut cocok untuk ditanami tanaman untuk berkebun pada dasarnya tanahnya sudah habis terkena bakaran dan juga keadaan tanahnya tidak terlalu lembab dan juga kering tapi sedang. Keadaan tersebut sangat cocok untuk tanaman yag berpotensi memakan waktu yang lama. Karena pemerintah menginginkan supaya pendapatan mereka bisa lebih baik dibanding sebelumnya.

Sejak dahulu masyarakat Parit Pacitan memang menggantungkan perekonomiannya dalam bidang pertanian dan nelayan. semua warga desa tersebut sehariharinya bermata pencaharian sebagai petani dan nelayan. Penghasilan para tani dan nelayan di desa ini sebelum adanya perkebunan karet tidak bisa dihitung dengan nilai namun mereka mementingkan hidup bergotong royong saling membantu satu sama lainnya, untuk itu tali persaudaraan mereka sangat kuat. Penghasilan yang dihasilkan dari sektor pertanian dan juga nelayan itu bisa dibilang sebagai penompang perekonomian desa Parit Pacitan. Karena memang dari dulu mereka juga sangat menggantungkan hidupnya dari sektor alam. 
Historia: Jurnal Program Studi Pendidikan Sejarah

Vol. 2 No. 2 (2017):17-32

P-ISSN 2301-8305

E- ISSN 2599-0063

Dengan adanya perkebunan karet masyarakat petani dan nelayan kini beralih profesi untuk bekerja sebagai petani perkebunan karet. Petani sekarang tidak berhubungan lagi dengan bos-bos sayur namun sekarang mereka berhubungan dengan toke karet. Yang dimana karet sangat menguntungkan bagi masyarakat setempat, Danpak dengan adanya perkebunan karet masyarakat hidupnya lebih meningkat dari pada masyarakat bekerja sebagai petani dan nelayan yang hasilnya tidak memuaskan, perkebunan karet sangat menunjang perekonomiannya bagi masyarakat, biasanya mereka ketika bekerja sebagai senada dengan yang dituturkan bapak Ngadirin, 55 petani sayur dan juga nelayan hanya mendapatkan 10-15 ribu per hari namun sekarang dengan berkebun karet mereka bisa mencapai 70-80 ribu per hari untuk itu kehidupan masyarakat semangkin bertambah tingkat perekonomiannya untuk itu gaya kehidupannya juga berubah dulu mereka hanya mempunyai sepeda ontel namun sekarang mereka sudah mempunyai motor bahkan mobil. Dulu rumah mereka masih berbentuk papan namun sekarang sudah berubah menjadi batu bata dan dicat sebagus mungkin, sebagian dari mereka juga sudah memiliki kebun karet sendiri dan ada yang sudah menjadi toke karet. Dengan berkebun karet kehidupan masyarakat sangat meningkat.

Tetapi tidak dapat dipungkiri Kehidupan yang ada di Desa Parit Pacitan tersebut tidak terlepas dari adanya hubungan sosial yang terjalin diantara mereka. Dalam menjalani kehidupan ini, sebagai makhluk sosial sudah tentu kita akan membutuhkan bantuan dari orang lain disekitar kita. Seperti halnya interaksi atau komunikasi yang ada di Desa Parit Pacitan ini. Proses interaksi yang terjadi di Desa Parit Pacitan ini sesuai dengan kajian teori yang dikemukakan oleh Talcot Parsons. Teorinya tersebut menjelaskan bahwa adanya 4 fungsi yang mutlak dibutuhkan bagi semua sistem sosial, meliputi adaptasi, pencapaian tujuan, integritas dan latensi 4 fungsi tersebut wajib dimiliki oleh semua sistem agar tetap bertahan.

a. Adaptasi (adaptation) yaitu fungsi yang amat penting disini sistem harus dapat beradaptasi dengan cara menanggulangi situasi eksternal yang gawat, dan sistem harus bisa menyesuaikan diri dengan lingkungan juga dapat menyesuaikan lingkungan untuk kebutuhannya. Sebelum adanya perkebunan karet kehidupan masyarakat masih sangat primitif, masyarakatnya belum maju dan belum mengenal adanya pendidikan, namun 
Historia: Jurnal Program Studi Pendidikan Sejarah

Vol. 2 No. 2 (2017):17-32

P-ISSN 2301-8305

E- ISSN 2599-0063

dengan hadirnya perkebunan karet masyarakat mulai beradaptasi dengan lingkungan perlahan-lahan masyarakat mulai meninggalkan pekerjaan yang lama dan mulai mengikuti situasi yang ada.

b. Pencapaian tujuan (Goal attainment) sangat penting dimana sistem harus bisa mendefinisikan dan mencapai tujuan utamanya. Berdasarkan teori di atas Desa Parit Pacitan merupakan desa yang dianggap masih pirmitif namun dengan hadirnya perkebunan karet desa tersebut harus dapat mengikuti alur waktu yang berkelanjutan yaitu membuat masyarakat bangkit akan kesadaran ekonomi, pendidikan, kesehatan, dan politik.

Desa Parit Pacitan dengan bekerja sebagai buruh karet dan penyadap karet merupakan pekerjaan yang amat singkat waktunya bisa dikatakan warga bekerja dari jam 6 pagi sampai jam 10 siang atau pergi jam 3 subuh sampai jam 8 pagi sudah pulang. Jika mempunyai banyak kebun maka warga masyarakat tinggal membagi waktu untuk menyadap karet ketempat yang lainnya dan hsilnya pun berbeda-beda tergantung dari banyaknya pohon yang di sadap. Apalagi pohon karet ini dapat dipanen hasilnya dengan hitungan hari bahkan minggu tidak perlu berbulan-bulan untuk menunggu hasil panennya apabila mangkok sudah penuh untuk tempat susu dan tidak ada lagi tempat yang lain maka segeralah dipanen Karena hasil dari panen tersebut juga akan dibelanjakan untuk keperluan sehari-hari bagi masarakat.

c. Integrasi (integrastion) artinya sebuah sistem harus mampu mengatur dan menjaga antar hubungan bagian-bagian yang menjadi komponennya. Selain itu mengatur dan mengelola ketiga fungsi (AGL). Adanya kerja sama dalam kehidupan bermasyarakat adanya suatu kerja sama diantara para anggota masyarakat sangatlah diperlukan. Adanya kerja sama yang terjalin diantara anggota masyarkat maka akan mempermudah untuk mencapai suatu tujuan bersama. Kerja sama tersebut juga membantu membentuk sebuah kerukunan yang ada dimasyarakat. Seperti halnya saat ada warga yang meninggal, para warga akan membantu prosesi pemakaman dari awal sampai selesai. Ataupun pada saat orang yang akan melakukan hajatan seperti pernikahan, sunatan, ataupun adanya kelahiran, maka semua warga saling membantu. Adanya hal seperti itu 
Historia: Jurnal Program Studi Pendidikan Sejarah

Vol. 2 No. 2 (2017):17-32

P-ISSN 2301-8305

E- ISSN 2599-0063

menunjukkan bahwa warga Parit Pacitan tersebut masih sangat menjnjung tinggi rasa kegotongroyongan dan tolong menolong.

d. Latensi (Latency) berarti sistem harus mampu berfungsi sebagai pemelihara pola, sebuah sistem harus memelihara dan memperbaiki motivasi pola-pola individu dan cultural. Dalam suatu tatanan masyarakat terjadinya interaksi itu akan berdanpak dengan adanya norma-norma yang mengatur warga sekitar untuk bertingkah laku. Norma sosial adalah sesuatu yang berada diluar individu, membatasi mereka dan mengendalikan tingkah laku mereka. Adapun norma-norma yang biasa ada dalam masyarakat secara sosiologis dibedakan menjadi 4, yaitu: cara (usage), kebiasaan (folkways), tata kelakuan (mores), dan adat istiadat (costum). Dalam suatu masyarakat keempat norma tersebut masih berlaku dalam tatanan kehidupan mereka sehari-hari.

Dengan adanya norma-norma tersebut, maka masyarakat akan senantiasa hidup dalam keteraturan yang telah disepakati bersama. Adanya keempat norma tersebut juga berlaku dan diterapkan untuk kehidupan sehari-hari oleh masyarakat di Desa Parit Pacitan. Aplikasi dari norma-norma tersebut dapat dilihat dari pemaparan berikut ini: pertama, norma cara (usage) terlihat dari bagaimana masyarakat memanfatkan kekayaan alam yang ada. Dimana beberapa waktu lalu Desa ini terkena kemarau dan kebakaran di desa tersebut. Masyarakat sekitar memanfaatkan kayu bakar yang telah menjadi arang. Dalam memanfaatkan kekayaan alam tersebut mereka masih menggunakan cara-cara yang sederhana dan dilakukan secara manual dengan tenaga manusia.

Seperti dalam pemotongan kayu bakar mereka masih menggunakan alat-alat yang tradisional dan setelah dipotong-potong dimasukkan kedalam karung dan didorong dengan gerobak yang mempunyai roda 1 lalu didorong oleh masyarakat. Kedua, kebiasaan (folkways) terlihat pada kebiasaan masyarakat Parit Pacitan ini dalam melakukan pekerjaan mereka. Dimana setelah adanya kebakaran desa ini beberapa waktu lalu, secara otomatis berpengaruh terhadap mata pencaharian mereka. Dulunya sebagian besar warga bekerja sebagai tani dan nelayan. Tetapi semenjak desa ini terkena musim kemarau dan kebakaran, sehingga banyak tanaman yang mati akibat kebakaran dan hutan-hutan juga kebakaran kemudian oleh mereka dimanfaatkan kayu-kayu bakar 
Historia: Jurnal Program Studi Pendidikan Sejarah

Vol. 2 No. 2 (2017):17-32

P-ISSN 2301-8305

E- ISSN 2599-0063

tersebut untuk diambil sebagai arang dan sebagai pekerjaan sampingan mereka. Perubahan mata pencaharian tersebut membuat mereka terbiasa oleh pekerjaan ganda yang harus mereka lakukan demi mencukupi kebutuhan sehari-hari. Biasanya mereka setiap pagi menanam kopi dan pinang dan sore harinya mereka memotong-motong kayu arang. Hal tersebut mereka lakukan secara terus-menerus setiap hari dan lama-kelamaan menjadi ritinitas ataupun kebiasaan dalam setiap harinya.

Ketiga, tata kelakuan (mores) dapat dilihat dari kehidupan sehari-hari masyarakat Parit Pacitan ini dalam menjalin hubungan antar sesama. Hal ini dapat dilihat dari bagaimana mereka menjaga hubungan dan kerja sama yang baik antar anggota-anggota masyarakat, seperti ketika ada warga yang membutuhkan bantuan pasti mereka akan senantiasa akan membantu. Saat terjadinya kebakaran beberapa waktu lalu mereka saling bahu membahu untuk saling menguatkan satu sama lain dalam menghadapi bencana tersebut.

Keempat, adat istiadat (custom) adanya norma ini bisa dibilang adalah adanya sebagai warisan turun-temurun dari nenk moyang. Hal itu juga dirasakan oleh warga Desa Parit Pacitan, dimana sejak dahulu telah menjaga adat istiadat yang ada di Desa Parit Pacitan tersebut. Seperti dalam acara pernikahan, kelahiran ataupun kematian. Misalnya dengan acara pernikahan, biasanya orang mempunyai hajat akan mengumpulkan para warga untuk membantu dalam prosesnya nanti, dari persiapan sampai nanti acara selesai. Biasanya dalam hal ini yang lebih berperan adalah para lakilaki. Untuk para ibu-ibu atau wanita mereka lebih ke urusan dalam seperti untuk masakmemasak biasanya warga sekitar menyebutnya "rewang". Begitu juga dengan kelahiran dan kematian.

Dengan berubahnya mata pencaharian di Desa Parit Pacitan berubah juga nilai pendapatan. Pendapatan merupakan segala macam uang yang diterima secara tetap oleh perorangan, keluarga atau organisasi misalnya upah, gaji, laba dan lain-lain. pendapatan itu sendiri digunakan untuk memenuhi kebutuhan keluarga, banyak pembiayaan yang harus dikeluarkan oleh keluarga, antara lain untuk pakaian, makanan, rumah atau tempat tinggal dan sebagian kecil untuk pendidikan. Karna tanpa adanya pendapatan maka keluarga tidak dapat memenuhi kebutuhan hidupnya. Pada dasarnya manusia 
Historia: Jurnal Program Studi Pendidikan Sejarah

Vol. 2 No. 2 (2017):17-32

P-ISSN 2301-8305

E- ISSN 2599-0063

mempunyai kebutuhan masing-masing dari kebutuhan yang primer hingga kebutuhan tersier.

\section{KESIMPULAN DAN SARAN}

Desa Parit Pacitan merupakan desa yang berada di kepulauan Riau, wilayah Kecamatan Kundur, Kabupaten Karimun. Dan bermata pencaharian nelayan, namun dengan adanya perubahan kehidupan maka terjadilah perubahan perekonomian masyarakat. Masyarakat tidak lagi bekerja sebagai nelayan namun masyarakat bermata pencaharian sebagai perkebunan karet.

Hasil penelitian ini pada tahun 2016 telah terjadi perubahan dalam bidang sosial dan ekonomi masyarakat yaitu tingkat pendidikan semangkin meningkat, dahulunya hanya berpendidikan sampai SD saja namun sekarang sudah mencapai keperguruan tinggi, interaksi sosial yang terjadi didalam masyarakat mulai memudar dikarenakan adanya perubahan mata pencaharian. Sebelum adanya perkebunan karet masyarakat bekerja mencari ikan di sungai namun dengan adanya perkebunan karet masyarakat tidak lagi mencari ikan disungai, mereka sudah bisa membeli ikan yang segar dipasar, Untuk itu pendapatan masyarakat mulai meningkat dan mempengaruhi gaya hidup mereka. Mereka sudah mempunyai rumah yang bagus, kendaraan, alat-alat elektronik dll sebagainya. Adapun saran yaitu diharapkan dapat menambah pengetahuan pembaca dalam mengembangkan dan meningkatkan kesejahteraan ekonomi masyarakat, sebagai referensi bagi masyarakat setempat dan sebagai acuan untuk penelitian selanjutnya.

\section{REFERENSI}

Ibrahim. (2015). Penelitian Kualitatif. Bandung : Alfabeta.

Parsons. (1951). Fungsionalisme Struktural Talcott Parsons. Jakarta : Liberty.

Saputri, C.D. (2012) Perubahan Sosial-Ekonomi Masyarakat Penambang Pasir Pasca Erupsi Merapi Tahun 2010 di dusun Kojor, Kelurahan Bojong, Kecamatan Mungkid, Kabupaten Magelang. Skripsi, tidak diterbitkan. Universitas Negeri Yogyakarta, Yogyakarta. 
Historia: Jurnal Program Studi Pendidikan Sejarah

Vol. 2 No. 2 (2017):17-32

P-ISSN 2301-8305

E- ISSN 2599-0063

Soekanto, Soejono. (2010). Sosiologi Suatu Pengantar, Jakarta : Raja Wali Pers.

Sugiyono, (2011). Metode penelitian Kualitatatif (Kualitatif dan R\&D, Bandung : Alfabeta. 